ELORE (ISSN 1456-3010), vol. $16-1 / 2009$.

Julkaisija: Suomen Kansantietouden Tutkijain Seura ry. [http://www.elore.fi/arkisto/1_09/art_hovi_1_09.pdf]

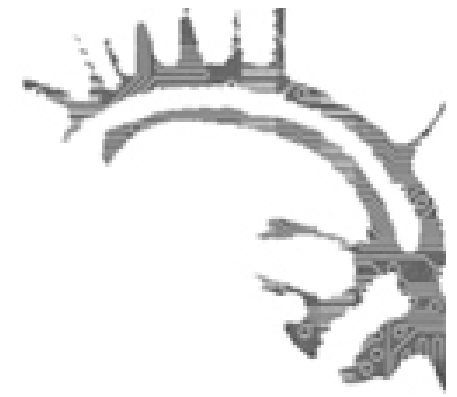

\title{
KULTTUURIPERINTÖ JA DRACULA-TURISMI
}

\author{
Tuomas Hovi
}

Tarkastelen tässä artikkelissa Dracula-turismin ja kulttuuriperinnön yhteyttä. Äkkiseltään Dracula-turismin ja kulttuuriperinnön yhdistäminen saattaa tuntua oudolta ajatukselta, mikäli Draculasta tulee mieleen pelkästään fiktiivinen vampyyrikreivi. Pyrin kuitenkin tässä artikkelissa esittämään miten kulttuuriperintö näkyy ja vaikuttaa Dracula-turismissa Romaniassa.

Dracula-turismilla tarkoitan turismia, joka liittyy joko historiallisena Draculana tunnettuun Vlad Seivästäjään tai fiktiiviseen vampyyrikreivi Draculaan. Vlad Seivästäjä hallitsi nykyisen Romanian eteläosaa, Valakian ruhtinaskuntaa 1400-luvulla. Vaikka Vlad Seivästäjä oli vallassa yhteensä vain vähän alle seitsemän vuotta, on hän maineensa vuoksi yksi kuuluisimmista hallitsijoista Romanian historiassa sekä yksi hyödynnetyimmistä historiallisista henkilöistä Romanian matkailuteollisuudessa. Toinen Dracula-turismin keskeinen kohde perustuu Bram Stokerin vuonna 1897 julkaistuun romaaniin Dracula ja erityisesti kirjan päähenkilöön vampyyrikreivi Draculaan. Tämä puoli Dracula-turismista pitää sisällään myös yleisemmin kauhuturismiin liittyviä piirteitä. (1) Dracula-turismia ylläpitävät ja tuottavat sekä romanialaiset että ulkomaalaiset matkanjärjestäjät. Dracula-turismissa Vlad Seivästäjä ja fiktiivinen Dracula yhdistetään usein yhdeksi ja samaksi henkilöksi. Tämä on aiheuttanut ristiriitaisia tunteita varsinkin Romaniassa, sillä se on usein tapahtunut muiden kuin romanialaisten itsensä ehdoilla. Yliluonnollisten piirteiden liittäminen Vlad Seivästäjään on nähty tapahtuvan historialliseen, Romanian kulttuurille merkittävään henkilöön liittyvän perinteen säilymisen kustannuksella. (Cosma, Pop \& Negrusa 2007, 2.)

Kulttuuriperintö ja etenkin sen englanninkielinen vastine heritage (2) ovat termejä joihin ei voi olla törmäämättä tutkittaessa kulttuuria. Kulttuuriperintö-termiä käytetään poliittisten tarkoitusperien ajamiseen ja kansallisen identiteetin vahvistamiseen, tärkeiksi katsottujen rakennusten, tapojen ja perinteen säilyttämiseen sekä taloudellisten intressien oikeuttamiseen. Etenkin matkailuteollisuudessa kulttuuripe- 


\section{KULTTUURIPERINTÖ JA DRACULA-TURISMI}

rintöä käytetään ja hyödynnetään jatkuvasti ja se nähdään merkittävänä resurssina. (Hall 1994, 180.) Kulttuuri ja kulttuuriperintö ovat tulleet niin merkittäväksi osaksi matkailua, että kulttuuriperinnöstä on muodostunut oma matkailuteollisuuden alansa: kulttuuriperintömatkailu, heritage tourism (Timothy \& Boyd 2003, 1).

Huolimatta kulttuuriperintö-termin yleisyydestä ja näennäisestä ymmärrettävyydestä sen merkitys vaihtelee. Laajimmillaan kulttuuriperinnön voidaan käsittää tarkoittavan melkein mitä vain kulttuurin muotoa. Kulttuuriperintöön voidaan katsoa kuuluvan erilaiset aineelliset ja aineettomat voimavarat, kuten rakennukset, museoiden esineet, juhlat, taide, festivaalit ja kulttuuriset tapahtumat. Myös luonnonnähtävyydet ja perinnemaisemat voidaan mieltää kulttuuriperinnöksi, silloin kun niille on annettu kulttuurisesti tärkeitä merkityksiä. (Timothy \& Boyd 2003, 3-4.)

Kulttuuriperinnön määrittely voi tapahtua joko ns. ylätasolla kuten esimerkiksi UNESCO:n tai maan hallituksen määrittelemänä tai ns. alatasolla yksittäisten ihmisten tai ihmisryhmien määrittelemänä. Kulttuuriperintöä ei siis ole sellaisenaan olemassa, ja se on aina määrittelyn ja rajanvedon tulos. Määrittelemällä jokin arvokkaaksi kulttuuriperinnöksi suljetaan jotain sen ulkopuolelle. Kulttuuriperinnön määrittely selkiytyy kun sitä verrataan historian käsitteeseen. Dallen J. Timothyn ja Stephen Boydin mukaan historia on menneisyyden tallentamista niin tarkkaan kuin se on sen hetkisen tiedon varassa mahdollista. Kulttuuriperintö on sellainen menneisyyden osa, aineellinen tai aineeton, minkä me määrittelemme tärkeäksi, säilyttämisen arvoiseksi ja aiemmilta sukupolvilta perityksi. (Timothy \& Boyd 2003, 4.) Näin ollen kulttuuriperintö ei ole mitään pysyvää, vaan se on alati määritelmien ja määrittelyjen armoilla. Sama koskee tietyssä määrin myös itse termiä.

\section{Dracula-PERINNE}

Dracula-turismissa Dracula-perinteellä on merkittävä asema. Dracula-perinteellä tarkoitan Vlad Seivästäjästä kertovia tarinoita sekä häneen liitettyjä käsityksiä. Vlad Seivästäjä hallitsi Valakian ruhtinaskuntaa kahden suurvallan, Unkarin ja Osmanien imperiumin välissä vuosina 1448, 1456-1462 ja 1476. Suurvaltojen aiheuttamien ulkoisten paineiden lisäksi hänen hallitsijakausiaan värittivät maan sisäiset valtataistelut kahden eri hallitsijasuvun välillä. Suhteellisen lyhyistä hallitsijakausista huolimatta Vlad Seivästäjä sai itselleen maineen, joka on säilynyt vuosisatojen ajan nykypäiviin asti. Romaniassa Vlad Seivästäjään on suhtauduttu positiivisemmin kuin Romanian ulkopuolella. Romaniassa Vlad on nähty hallitsijana, joka puolusti maansa ja kansansa itsenäisyyttä ulkopuolista vihollista vastaan. Lisäksi Vlad on nähty kristinuskon puolustajana uhaksi koettua islamia vastaan. Romanialaisessa perinteessä Vlad esiintyy talonpoikien ja ns. tavallisen kansan puolustajana pahoiksi ja ilkeiksi koettua aatelistoa vastaan. Vladia onkin pidetty oikeuden puolustajana, ja romanialaiset ovat arvostaneet Vladin ankaraa suhtautumista rikollisuutta kohtaan. Nämä näkemykset Vladista ovat myös nykyään voimissaan Romaniassa. Romanialaisen historioitsija Lucian Boian mukaan romanialaiset unelmoivat vielä nykyisinkin Vlad Seivästäjästä tai uudesta Vlad 


\section{TUOMAS Hovi}

Seivästäjästä aina kun he tuntevat olevansa epävarmoja maansa hallitsijoista tai kun he tuntevat, että nämä ovat heidät hylänneet. "Miksi et tule uudestaan valtias Seivästäjä?” on Boian mukaan edelleen yleinen rukous tai manaus romanialaisten keskuudessa edelleen. (Boia 2001, 230.) Toisaalta Vlad Seivästäjä on nähty silloin tällöin myös romanialaisessa historiantutkimuksessa verenhimoisena tyrannina ja mielipuolisena sadistina. Negatiivisempi kuva Vladista on ollut vallalla kuitenkin lähinnä Romanian ulkopuolella. (Treptow 2000, 10-11, 168-169 \& 178.)

Vlad Seivästäjän maine on ollut kahtalainen aina 1400-luvulta alkaen 2000-luvulle saakka. Toisaalta häntä on pidetty julmana, mutta hyvänä ja oikeudenmukaisena hallitsijana ja toisaalta verenhimoisena tyrannina, jonka sanotaan tapattaneen ja kiduttaneen jopa lähemmäs 100000 ihmistä. Vladin mainetta lisäsi hänen lempiteloitustavakseen sanottu seivästäminen, mistä myös hänen lisänimensä juontuu. Valakian ulkopuolella Vlad Seivästäjästä käytettiin kuitenkin pääasiassa nimeä Dracula, jonka hän peri isältään Vlad Draculilta. Saksalaisissa ja venäläisissä tarinoissa Vladista käytetään nimeä Dracula, kun taas romanialaisissa tarinoissa hänestä käytetään nimeä Vlad Seivästäjä. Dracula-perinne sai alkunsa jo Vlad Seivästäjän elinaikana hänestä kertovien alun perin 1400-luvulla tehtyjen saksalaisten ja venäläisten tarinoiden muodossa. Saksankieliset tarinat levisivät myöhemmin 1500- ja 1600-luvuilla ympäri Eurooppaa ja venäläiset tarinat puolestaan levisivät nimensä mukaisesti Venäjälle. Saksalaisten ja venäläisten painettujen tarinoiden lisäksi nykyisen Romanian alueella syntyi 1400-luvulla myös suullinen Vladista kertova tarinaperinne, joka toimi osittain saksalaisten ja venäläisten tarinoiden pohjana. Edellä mainittujen lisäksi Vlad Seivästäjään liittyviä kertomuksia löytyy mm. turkkilaisista ja bysanttilaisista lähteistä sekä paavi Pius II:n muistelmista. (Treptow 2000,16-17, 190, 206.) Saksalaiset, venäläiset ja romanialaiset tarinat ovat kuitenkin laajimmin levinneet ja siten myös tunnetuinta Dracula-perinnettä.

Saksalaiset, venäläiset ja romanialaiset tarinat antavat kohteestaan erilaisen kuvan. Saksalaiset tarinat kirjoitettiin alun perin propagandasyistä ja ne koostuvat lyhyistä episodeista, jotka kuvaavat Vladin hirmutekoja. Näissä tarinoissa hirmuteot ovat selvästi yliampuvia groteskiudessaan ja niissä Vladia kuvataan sairaalloiseksi tyranniksi ja verenhimoiseksi mielipuoleksi. Tarinoissa kuvaillaan lukuisia kidutus- ja teloitusmetodeja hyvin yksityiskohtaisesti ja alleviivataan Draculan eli Vladin omituisuutta ja tyrannimaisuutta. Esimerkkinä tällaisesta tarinasta toimii alla oleva lainaus Nürnbergissä vuonna 1488 painetusta Dracula-kertomuksesta Die geschicht Dracole waide:

"Hän antoi seivästää ihmisiä sivuttain, kaikenlaista väkeä: kristittyjä, juutalaisia ja pakanoita. Ihmiset liikkuivat ja vääntelehtivät sikin sokin kuin sammakot. Sen jälkeen hän antoi myös seivästää heidän kätensä ja jalkansa. Sitten hän puhui usein tähän tapaan: Oi, miten sulavilta he näyttävät. Ja niin hän sai mielihyvää ja nautintoa.” (Harmening 1983, 33.) (3)

Venäläiset tarinat koostuvat pidemmistä episodeista, jotka on koottu kronologiseksi yhtenäiseksi tarinaksi. Venäläisissä tarinoissa Vlad kuvataan ankarana, mutta oikeudenmukaisena ja viisaana hallitsijana. Näiden tarinoiden antama kuva Vladista onkin huomattavasti positiivisempi kuin saksalaisten tarinoiden, ja Venäjällä tarinat miellettiin ikään kuin ohjeistuksina ja esimerkkeinä hallitsijoille. Tarinoissa Vladiin 


\section{KULTTUURIPERINTÖ JA DRACULA-TURISMI}

liitetty julmuus esitetään hyvän hallitsijan ominaisuudeksi ja oikeudeksi. (Andreescu 1999, 205; Striedter 1961, 414-415, 426.) Vladista kertovat tarinat vaikuttivat myöhemmin venäläiseen folkloreen ja etenkin Iivana Julmasta kertoviin kansantarinoihin (Perrie 1987, 96-99). Tarinoiden taustalla on epäilemättä myös kansainvälisiä hallitsijan julmuutta koskevia tarinamotiiveja, mutta muutama tarina on niin samanlainen, ettei yhteyttä venäläisten Dracula-tarinoiden ja Iivana Julmaan liittyvän tarinaperinteen välillä ole syytä epäillä. Esimerkiksi sekä saksalaisissa että venäläisissä Dracula-tarinoissa kuvaillaan tapahtumaa, jossa Vlad naulauttaa epäkohteliaiden lähettiläiden lakit heidän päihinsä kiinni. Sama episodi tunnetaan myös Iivana Julmaan liittyvissä tarinoista, mutta niissä toimijana on Iivana Julma Vlad Seivästäjän sijaan. (Andreescu 1999, 196; Harmening 1983, 36; Perrie 1987, 99.)

Romanialaisia Vlad Seivästäjästä kertovia yksittäisiä suullisia tarinoita on kerätty ja julkaistu 1800- ja 1900-luvuilla. Vuonna 1969 Arefun kylässä tehdyissä kenttätöissä kerättiin 25 Vlad Seivästäjästä kertovaa tarinaa. Suurin osa näistä tarinoista on sellaisia joita ei löydy saksalaisten tai venäläisten tarinoiden joukosta. Romanialaiset tarinat kuvaavat Vlad Seivästäjän kaikkein positiivisimmassa valossa. Tämä positiivinen suhtautuminen näkyy selvästi vuonna 1969 tehtyjen tarinakeräysten yhteydessä tallennetuissa informanttien kommenteissa. Monet informantit selittivät kertomiaan tarinoita sekä perustelivat ja ymmärsivät Vladin toimintaa. (Ene 1976, 582-587.) Romanian suullinen Dracula-tarinaperinne on edelleen osittain elävää perinnettä ja sitä hyödynnetään Dracula-turismissa. Vlad Seivästäjä korjautti elinaikanaan Arefun kylän lähellä sijainneen Poenarin linnan. Vladin elämä linnassa antoi aiheen tarinoille, joista neljä on säilynyt nykypäiviin asti. Tarinat ovat edelleen elävää perinnettä Arefun kylässä, ja tarinoita kerrotaan nykyisin lähinnä turisteille heidän vieraillessaan linnan raunioilla. Kylän ja linnanraunioiden tiivis yhteys ovat todennäköisesti auttaneet tarinoita pysymään ihmisten muistissa aikojen kuluessa, ja nykyisin turismi itsessään pitää yllä kyseisten tarinoiden säilymistä elävänä perinteenä. Eräs yleinen linnanraunioihin ja Vlad Seivästäjään liittyvä tarina käsittelee Vladin pakoa Poenarin linnasta turkkilaisen vihollisarmeijan lähestyessä (Ene 1976, 588).

Tarinan mukaan eräs turkkilaisten armeijaan soluttautunut Vlad Seivästäjälle myötämielinen sotilas varoitti Vladia vihollisten lähestymisestä ampumalla varoitusviestin sisältävän nuolen linnan ikkunasta läpi. Vlad pakeni yön pimeydessä Arefun kyläläisten opastaessa hänet vuoriston läpi Transilvanian puolelle. Tarinan mukaan Vlad hämäsi häntä seuraavia turkkilaisia kengittämällä hevosensa väärinpäin. Pakomatkan onnistuttua Vlad antoi häntä opastaneille talonpojille palkinnoksi omistusoikeuden kylää ympäröiviin maihin. (Ene 1976, 588.) (4) Muita tunnettuja Vlad Seivästäjästä kertovia tarinoita ovat mm. Vlad Seivästäjän linnan rakentaminen, Vlad Seivästäjän kätkemä aarre sekä köyhien, varkaiden ja vammautuneiden elävältä polttaminen. Näistä tarinoista etenkin viimeksi mainittu on erittäin mielenkiintoinen. Tarinan mukaan Vlad kokosi kaikki maansa köyhät ja vähäosaiset erääseen rakennukseen, jonne hän oli kattanut juhla-aterian. Vlad lupasi syömään tulleille paremman elämän. Hän käski teljetä rakennuksen ovet ja ikkunat sekä polttaa talon ja samalla sen sisällä olevat ihmiset. Sama episodi löytyy myös saksalaisista ja venäläisistä tarinoista, joissa tarinalla kuvataan Vladin julmuutta. Vuonna 1969 tarinan toisinnon kertonut romanialainen 


\section{TUOMAS Hovi}

haastateltava kuitenkin puolusti Vladin tekoa sanoen sen olleen maalle pelkästään hyväksi ja Vladin toimineen täysin oikein. (Ene 1976, 583-585.)

Historiallisten tekstien ja kertomusperinteen lisäksi Dracula-perinteeseen on liitetty uusia piirteitä 1900-luvun jälkimmäiseltä puoliskolta lähtien, jolloin Vlad Seivästäjä alettiin liittää irlantilaisen kirjailijan Bram Stokerin luomaan fiktiiviseen vampyyrikreivi Draculan hahmoon. Vampyyrikreivi Dracula syntyi vuonna 1897 Stokerin julkaistua maailmankuulun romaaninsa Draculan. Kirjan ilmestymisen jälkeen Draculasta on tullut yksi populaarikulttuurin tunnetuimmista hahmoista lukuisten kirjojen, TV-sarjojen, tietokonepelien ja elokuvien kautta. Draculasta on muodostunut jopa yleisesti käytetty synonyymi vampyyrille (Miller 2006, 3). Nykyään fiktiivisen vampyyri Draculan voidaan katsoa muotoutuneen alkuperäisestä romaanin henkilöhahmosta yleiseksi ja itsenäiseksi populaarikulttuurin hahmoksi, joka elää erillään Stokerin romaanista. Nimenomaan tätä vuosikymmenien aikana kehittynyttä hahmoa hyödynnetään Dracula-turismissa, se ei siis ole enää täysin samanlainen kuin Stokerin kirjassa alun perin esiintynyt kreivi Dracula. Fiktiivisen ja historiallisen Draculan yhdistäminen on niin yleistä, että sen voidaan katsoa muodostavan oman pseudoperinteen, joka elää mediassa ja Internetissä vaikuttaen myös Dracula-turismiin. Populaarikulttuurin vaikutus voidaankin nähdä yhtenä merkittävimmistä syistä siihen miksi historiallinen ja fiktiivinen Dracula sekoittuvat niin usein toisiinsa (Hovi 2008a, 82-83).

\section{Kahdesta Draculasta yHdeksi?}

Fiktiivisen vampyyrikreivin ja historiallisen hallitsijan yhdistäminen ja sulauttaminen toisiinsa on mielenkiintoinen ilmiö. Eräs selitys sille miksi hahmojen yhdistäminen on niin yleistä, johtuu yksinkertaisesti nimestä Dracula. Läntisen populaarikulttuurin muovaama käsitys Draculasta on niin vahva, että pelkkä nimi riittää yhdistämään ajatukset kauhuun ja vampyyreihin. (5)

Toinen selitys Dracula-hahmojen yhdistämiselle on anakronistinen lähestymistapa historiallista Draculaa, Vlad Seivästäjää koskevien lähteiden ja tekstien käyttöön. Vlad Seivästäjästä kertovia tarinoita, etenkin saksalaisia, on luettu ikään kuin "vampyyrisilmälasien" läpi. 1400- ja 1500-luvulla kirjoitettuja tekstejä on luettu romaanin ja myöhemmän populaarikulttuurin muodostaman kuvan läpi, ja vanhoista tarinoista on hakemalla haettu viitteitä vampyyri Draculaan. Historiallisen ja fiktiivisen Draculan sekoittuminen on ollut yleistä mediassa ja myös akateemisten tutkijoiden keskuudessa.

Akateemisten tutkijoiden keskuudessa Vlad Seivästäjän ja fiktiivisen Draculan yhteyttä ovat vahvimmin korostaneet kaksi Yhdysvalloissa toiminutta historian professoria, Raymond T. McNally ja Radu Florescu. Vaikka McNally ja Florescu eivät olleet ensimmäisiä, jotka halusivat yhdistää fiktiivisen Draculan ja Vlad Seivästäjän toisiinsa, ovat he edelleen tunnetuimmat tämän yhteyden esiintuojista (Miller 2000, 180-181). McNallyn ja Florescun menestynyt kirja In Search of Dracula toimii hyvänä esimerkkinä "vampyyrisilmälasien" käytöstä. Kirjassaan he esimerkiksi tulkitsevat saksalaisen 


\section{KULTTUURIPERINTÖ JA DRACULA-TURISMI}

1400-luvulla eläneen runoilijan Michel Beheimin Vlad Seivästäjästä kertovaa runoa. McNallylle ja Floresculle runo toimii todisteena Vlad Seivästäjän vampyyriudesta. Heidän mukaansa Dracula (Vlad) kastaa runossa leivän ihmisvereen ja syö sen. Tämä todistaa tutkijoiden mukaan Vladin olevan siis eräänlainen elävä vampyyri. (McNally \& Florescu 1994, 85.) Tämä jo sinällään hatara tulkinta perustuu myöhemmän tutkimuksen mukaan kuitenkin käännösvirheeseen. Runossa mainitaan miten Dracula (Vlad) nautti nähdessään veren virtaavan, ja hänellä oli tapanaan pestä kätensä veressä (Gille \& Spriewald 1968, 290). Myös Vladin paljon käyttämässä teloitusmenetelmässä, seivästämisessä, on haluttu nähdä yhteys vampyyrien seivästämiseen. (Miller 2000, 213-214.) Tutkijoiden keskuudessa käsitykset Vlad Seivästäjän ja vampyyrikreivin oletetusta yhteydestä ovat viime vuosina muuttuneet varovaisemmiksi, mutta niin mediassa kuin Dracula-turismissakin hahmojen sekoittuminen jatkuu edelleen (Miller 2000, 12-15).

Käsiteltäessä fiktiivisen ja historiallisen Draculan yhteyttä on aiheellista tarkastella sitä kuinka paljon Bram Stoker tiesi Vlad Seivästäjästä ja Romanian historiasta romaania kirjoittaessaan. Vlad Seivästäjää on pidetty Stokerin vampyyrikreivin innoittajana tai esikuvana ja Stokerin kirjan on jopa sanottu pohjautuvan suoraan Vlad Seivästäjän elämään. Varmasti voidaan sanoa vain, että Stoker lainasi kirjansa hahmolle nimen Dracula sekä lyhyen historiallista tapausta kuvaavan kohdan Romanian historiaa käsittelevästä kirjasta. Nämä kaksi asiaa ovat ainoita, jotka Stokerin voidaan varmasti sanoa lainanneen Vlad Seivästäjältä. (Miller 2001, 180-189.)

Vlad Seivästäjä mainitaan edelleen usein varsinkin mediassa vampyyrikreivi Draculan esikuvana tai historiallisena lähteenä. Nämä esimerkit kertovat halusta ja jopa tarpeesta yhdistää kaksi Draculaa toisiinsa. Mainitsemisen arvoista on, että Vlad Seivästäjää ei ole yhdistetty vampyyreihin ennen 1900-lukua. Edes saksalaisissa kauhutarinoissa häntä ei yhdistetty vampyyreihin, eikä häntä missään vaiheessa ole yhdistetty vampyyreihin tai muihin vastaaviin uskomusolentoihin myöskään romanialaisessa suullisessa perinteessä. Romaniassa vampyyrit ovat olleet keskeinen kansanuskoon kuulunut uskomusolento, mutta tästä huolimatta alkuperäistä romanialaista vampyyriperinnettä ei ole havaintojeni mukaan hyödynnetty Dracula-turismissa. Turismissa kylläkin hyödynnetään populaarikulttuurista tuttua mielikuvaa Romaniasta vampyyrien maana, mutta turismissa hyödynnettävä käsitys vampyyreistä ei nojaudu romanialaiseen vampyyriperinteeseen.

Tämä voi johtua osittain siitä, että kansanperinteen vampyyri eroaa esimerkiksi Stokerin kuvaamasta vampyyrista monella tavalla. Eräs silmiinpistävimmistä eroista liittyy vampyyrin yhteiskunnalliseen asemaan. Kansanperinteen vampyyrit ovat perinteisesti olleet alun perin maanviljelijöitä ja ovat elävinä kuolleina vaikuttaneet vanhassa kyläyhteisössään. Bram Stokerin kirjassa esiintyvä vampyyri oli puolestaan 1800-luvun vampyyri- ja kauhukirjallisuudelle tyypilliseen tapaan juuri aatelinen, joka toimii ylempien sosiaaliluokkien piirissä. (Frayling 1991, 37-60; Murgoci 1998; Perkowski 1998, 45.)

Romanialaisessa kansanperinteessä Vlad Seivästäjästä ei myöskään käytetty nimeä Dracula, vaan Vlad Seivästäjä, ja Romaniassa nimi Dracula onkin yhdistetty nimenomaan Vlad Seivästäjän isään, ei Vlad Seivästäjään itseensä. Dracula-nimen 


\section{TUOMAS Hovi}

liittäminen Vlad Seivästäjään on romanialaisille vierasta, ja tämä on osasyy siihen, miksi romanialaiset vieroksuvat fiktiivisen ja historiallisen Draculan yhdistämistä esimerkiksi turismissa. Yksi suurimmista syistä miksi Dracula-turismia on Romaniassa vastustettu, on maan historialle tärkeän kansallissankarin yhdistäminen länsimaiseen fiktiiviseen hirviöön, vampyyrikreivi Draculaan (Cosma, Pop \& Negrusa 2007, 2).

\section{Dracula-turismi Romaniassa}

Dracula-turismi alkoi Romaniassa 1960-luvun lopulla sosialistisen Romanian alkaessa avautua länsimaisille turisteille. Aluksi Dracula-turismi oli hyvin pienimuotoista. Turistit tulivat etsimään Bram Stokerin Draculan kirjallisia ja yliluonnollisia juuria, mutta eivät kuitenkaan löytäneet etsimäänsä. Länsimainen vampyyri Dracula oli lähes tuntematon Romaniassa - Stokerin romaani käännettiin romaniaksi vasta 1990-luvun alussa - eikä sopivia vierailukohteita ollut olemassa. Vähitellen turismi alkoi kasvaa ja sopivia turistikohteita alkoi löytyä. Eräs turistien eniten etsimistä kohteista oli Draculan linna. Stokerin romaanissa linna sijaitsi Borgon solan lähellä Pohjois-Romaniassa, mutta koska romaani oli fiktiota, ei linnaa todellisuudessa ollut olemassakaan. Historiallisen Draculan, Vlad Seivästäjän rauniolinna Poenari voitiin nähdä oikeana Draculan linnana, mutta se oli raunioina ja hankalien kulkuyhteyksien päässä. Tämä johti Braşovin kaupungin lähellä Transilvaniassa sijaitsevan Branin linnan muuttumisen tai muuttamisen Draculan linnaksi. Linna sijaitsi täysin eri paikassa kuin Draculan linna Stokerin romaanissa ja sillä oli vain löyhä yhteys Vlad Seivästäjään, Vladin tiedetään viettäneen linnassa muutaman yön. Branin linna mainitaan edelleen Draculan linnana mm. mediassa ja etenkin Dracula-turismissa. (Light 2007, 752-754.)

Kasvaneeseen kiinnostukseen ja Dracula-turismin lisääntymiseen vaikutti kirja In Search of Dracula, jossa Vlad Seivästäjä ja fiktiivinen Dracula yhdistetään hyvin suorasti toisiinsa. Laajalti menestynyt ja luettu teos innosti turisteja tutustumaan Vlad Seivästäjään ja Draculaan paikan päällä. (Light 2007, 755.) Romaniassa maahan tuleviin turisteihin suhtauduttiin eri tavoin, ja esimerkiksi Romanian hallituksen suhtautumista Dracula-turismiin voi kuvata ristiriitaiseksi. Toisaalta länsimaisia matkailijoita ja heidän mukanaan tuomaa valuuttaa haluttiin maahan, mutta toisaalta Romanian historiallisen sankarin yhdistämistä länsimaiseen vampyyrihirviöön vierastettiin. Dracula-turismin pelättiin pilaavan Vlad Seivästäjän maineen. (Light 2007, 757.)

Romanian sosialistisen hallituksen historiankäsityksen ja -tulkinnan muuttuessa 1970-luvulla nationalistisempaan suuntaan, Vlad Seivästäjää alettiin pitää yhtenä Romanian historian kansallissankareista. Romanian hallitus ei ollut mielissään kansallissankarin yhdistämisestä länsimaiseen hirviöön. Dracula-turismi oli problemaattista Romanian hallitukselle myös poliittisista syistä. Nicolae Ceauşescu halusi korottaa maansa profililia ja tuoda itseään esille kansainvälisenä valtiomiehenä. Dracula-turismin avulla maahan tuli länsimaisia turisteja, mutta toisaalta se ylläpiti stereotyyppistä kuvaa Romaniasta taikauskoisena vampyyrien asuttamana maana. Dracula-turismi ja siihen liittyvä taikauskoisuus ei myöskään sopinut hallituksen ajamaan kuvaan sosialistisesta, 


\section{KULTTUURIPERINTÖ JA DRACULA-TURISMI}

uudesta ja tieteeseen nojautuvasta Romaniasta. (Light 2007, 755.)

Dracula turismi alkoi kehittyä 1970-luvulla kahteen suuntaan. Romanian hallitus pyrki hoitamaan turismia omilla ehdoillaan, ja hallituksen virallinen Draculamatkapaketti keskittyikin Vlad Seivästäjään liittyviin paikkoihin ja historiaan. Paketissa pyrittiin sekä antamaan mahdollisimman hyvä kuva Vlad Seivästäjästä että oikaisemaan In Search of Draculassa esitetty kuva Vladista. Virallinen Dracula-paketti pyrki haastamaan ja kiistämään länsimaisen representaation Romanian kulttuurisesta identiteetistä ja historiasta. Dracula-turismi samoin kuin muukin turismi väheni 1980-luvulla hallituksen kiristäessä otetta Romaniassa. (6) (Light 2007, 754-758.)

Vuoden 1989 vallankumouksen jälkeen Dracula-turismi alkoi taas pikkuhiljaa lisääntyä, mutta maan hallituksen suhtautuminen pysyi ristiriitaisena. Romania pyrki 1990-luvulla lähemmäs läntistä Eurooppaa hakemalla sekä NATO:n että EU:n jäseneksi. On ymmärrettävää, ettei hallitus halunnut tukea Romanian länsimaihin nähden toiseutta vahvistavaa Dracula-turismia. Romanian hallituksen kanta muuttui kuitenkin 1990-luvun lopussa maan hallituksen alkaessa kehittää "Dracula Park" -teemapuistohanketta. Projektin tarkoituksena oli rakentaa suuri Dracula-aiheinen teemapuisto keskiaikaisen Sighişoaran kaupungin yhteyteen. Tarkoituksena oli hallita Dracula-turismia Romanian omista lähtökohdista käsin. (Iordanova 2007, 50-51; Light 2007, 758.)

Projekti kohtasi kuitenkin valtavaa vastarintaa mm. kirkon, akateemisen maailman, EU:n ja jopa Iso-Britannian prinssi Charlesin taholta. Projektin katsottiin loukkaavan ja vääristävän Romanian historiaa ja perinnettä sekä vahvistavan stereotyyppistä kuvaa Romaniasta. Erityisen vastustuksen kohteena oli teemapuiston aiottu sijoittamispaikka, sillä Sighișoaran kaupunki on UNESCO:n maailmanperintökohde. Kaupungin asukkaiden keskuudessa suhtautuminen Dracula Park -teemapuistoon oli ristiriitaista. Hankkeen kannattajien mielestä hanke toisi kaupunkiin töitä ja rahaa, mikä voitaisiin käyttää kaupungin suojeluun. Hankkeen vastustajien mielestä hanke puolestaan vaarantaisi kaupungin imagoa ja kulttuuriperintöä. (Jamal \& Tamase 2005, 445.) Vastustuksen johdosta teemapuiston sijoituspaikka siirrettiin lähemmäs maan pääkaupunkia Bukarestia, mutta projekti ei kuitenkaan koskaan saanut tuulta alleen ja projekti hylättiin vuonna 2006. (Cosma, Pop \& Negrusa 2007, 48.) Dracula-turismia on määrittänyt 1970-luvulta nykypäiviin asti ristiriidat eri tahojen välillä suhtautumisessa kulttuuriperintöön ja sen vaalimiseen, matkailuteollisuuteen, stereotypioihin ja fiktioon.

\section{TURISMI, KULTTUURIPERINTÖ JA AUTENTTISUUDEN KRITIIKKI}

Kulttuuriperintökohteen autenttisuus on yksi matkailuteollisuuden ja erityisesti kulttuuriperintöturismin tutkimuksessa eniten keskustelua ja kritiikkiä herättäneistä aiheista. Matkailuteollisuudessa perinteen käyttö elämyksien aikaansaamiseksi on muotoutunut perinneteollisuudeksi. Perinneteollisuuden on nähty muodostavan uhan perinteen autenttisuudelle. Tutkijoiden huolena on ollut perinteen kaupallistuminen ja historiallisen "oikean" aineksen muuttuminen symboliseksi (Aarnipuu 2008, 216). 


\section{TuOMAS Hovi}

Perinteisesti autenttisia kohteita ja autenttisuuden kokemista on pidetty matkailualalla turistien kannalta keskeisenä. Dracula-turismissa etenkin sen kritisoijat ovat korostaneet autenttisuuden merkitystä ja arvostelleet sen puutetta. Dracula-turismin on nähty väärentävän maan kulttuuria ja historiaa, siis toisin sanoen antavan maasta epäautenttisen kuvan. (Cosma, Pop \& Negrusa 2007, 40 \& 51; Jamal \& Tanase 2005, 446.)

Autenttisuus on moniselitteinen ja märittelyä vaativa käsite, eikä matkailijan käsitys autenttisesta ole välttämättä sama kuin akateeminen käsitys autenttisuudesta. (Timothy \& Boyd 2003, 239, 255.) Antropologi Charles Lindholm on jakanut autenttisuuden historialliseen tai genealogiseen alkuperään nojautuvaan autenttisuuteen sekä identiteettiin tai yhteyteen nojautuvaan sisällölliseen autenttisuuteen (Lindholm 2008, 2). Kaj Zimmerbauerin puolestaan tulkitsee autenttisuuden löytyvän tarkastelukulmasta ja aikaulottuvuudesta (Zimmerbauer 2001, 126).

Mielestäni autenttisuutta voidaan tarkastella toisaalta autenttisuuden kokemisen ja toisaalta historialliseen alkuperään perustuvan autenttisuuden avulla (Hovi 2008b, 81, 85). Esimerkiksi Branin linna Transilvaniassa on keskeinen Draculaturismin kohde, ja sitä mainostetaan sekä autenttisena keskiaikaisena linnana että erityisesti Draculan linnana. Linnan voidaan tieteellisesti todistaa olevan keskiaikainen transilvanialainen linna, jolloin sen autenttisuus keskiaikaisena linnana nojautuu sen historialliseen alkuperään. Autenttinen Draculan linna se ei kuitenkaan ole, jos tällä tarkoitetaan Vlad Seivästäjän tai kreivi Draculan linnaa. Todisteilla ei välttämättä ole turistille merkitystä, ja hän voi kokea Branin linnan autenttiseksi Draculan linnaksi ilman todisteita sen alkuperästä ja historiallisista kytköksistä Vladiin tai kreivi Draculaan. Turisti voi siis saada linnasta autenttisen kokemuksen Draculan linnana, vaikkei linna olekaan historiallisesti autenttinen Draculan linna. Koettu autenttisuus ja historiaan nojautuva autenttisuus voivat siis olla kaksi eri asiaa.

Kaj Zimmerbauerin mukaan autenttisuus elää nykyään enemmänkin mielikuvissa ja stereotypioissa kuin todellisuudessa (Zimmerbauer 2001, 125). Stereotypiat ovat kulttuurisia yleistyksiä tai ihmisten yhteisesti jakaman kulttuurin malleja, joiden taustalla on ihmisten omien odotusten mukainen maailma (Karvonen 1997, 64-65). Stereotypioiden käytöllä on matkailuteollisuudessa merkittävä osuus. Erityisen selvästi tämä tulee ilmi matkailun markkinoinnissa, missä matkailijalle täytyy tarjota toisaalta turvallisuutta, toisaalta eksotiikkaa ja uuden kokemista. Tällöin stereotypioiden avulla luotu kuva autenttisuudesta saattaa torjua pettymyksiä ja kulttuurisokkia (Zimmerbauer 2001, 125-126). Riskinä saattaa kuitenkin olla esitetyn kulttuurin väheksyminen ja kohteen toiseuteen nojaava väärentävä kuva matkakohteesta ja sen kulttuurista. Dracula-turismissa käytetyt stereotypiat Romaniasta salaperäisenä ja menneisyyteen sijoittuvana taianomaisena paikkana lukitsevat myös Romanian muun kulttuurin ja maan asukkaat tähän diskurssiin. Dracula-turismista käydyssä keskustelussa autenttisuuden kritiikki onkin ollut yksi merkittävimmistä syistä turismin vastustamiselle (Iordanova 2007, 47). 


\section{KULTTUURIPERINTÖ JA DRACULA-TURISMI}

\section{Dracula-TURISMi ja KULTTUURIPERINTÖKOHTEET}

Vaikka Dracula-turismia ei sinällään voi kutsua kulttuuriperintöturismiksi, kulttuuriperintö näyttäytyy siinä kuitenkin mielenkiintoisella tavalla. Merkittävä osa Draculaturismia ovat matkatoimistojen järjestämät Dracula-kierrokset, joilla vieraillaan joko historialliseen, fiktiiviseen tai molempiin Dracula-hahmoihin liitetyissä paikoissa. Kierroksien kohteina on myös linnoja, palatseja tai raunioita, keskiaikaisia kaupunkeja ja kohteita jotka eivät näennäisesti liity kumpaankaan Draculaan.

Selvimmin kulttuuriperintö on nähtävissä kohteissa, jotka liittyvät historialliseen Draculaan. Esimerkkinä tällaisesta kohteesta on mm. Târgovişten kaupungissa sijaitsevat ruhtinaanpalatsin rauniot sekä Curtea de Argeşin kaupungin lähellä sijaitsevat Poenarin linnanrauniot. Molempia raunioita mainostetaan lähinnä Vlad Seivästäjän avulla, vaikka niihin kumpaankin liittyy myös paljon muuta historiaa. Kumpikin kohde liittyy kiinteästi Dracula-perinteeseen, sillä niihin liittyy Vladista kertovia historiallisia tarinoita, joita myös hyödynnetään kohteiden markkinoinnissa ja niiden narratiivisessa tuottamisessa. Nämä tarinat ovat nimenomaan romanialaisesta suullisesta tarinaperinteestä tunnettuja tarinoita, joskin osa Târgovișten linnanraunioihin liittyvistä tarinoista tunnetaan myös saksalaisissa ja venäläisissä tarinoissa. Poenarin ja Târgovişten linnanrauniot ovat kummatkin museoituja kohteita. Tekemällä raunioista museoituja kohteita, ne on nähty säilyttämisen ja esittelyn arvoisiksi, toisin sanoen siis kulttuuriperinnön kannalta arvokkaiksi kohteiksi. Raunioihin liitetyt romanialaisesta kansanperinteestä tutut tarinat sitovat kohteet mielestäni tiettyjä muita Draculaturismin kohteita tiukemmin nimenomaan romanialaiseen kulttuuriperintöön, toisin kuin esimerkiksi tietyt Stokerin kirjaan liittyvät kohteet.

Erityisen kiinnostavia ovat Dracula-kierrosten kohteet, jotka eivät liity kumpaankaan Draculaan. Tällaisia ovat esimerkiksi Biertanin kaupunki linnoitettuine kirkkoineen, Bukovinan maalauksin koristellut luostarit sekä Peleşin linna. Näistä jokainen on mukana monissa eri Dracula-kierroksissa, vaikkei niillä ole mitään yhteyttä kumpaankaan Draculaan. Erityisesti Peleşin linna on Dracula-kierrosten kohteena mielenkiintoinen. Tämä 1800-luvun lopussa Romanian kuninkaallisille rakennettu linna on mukana lähes kaikissa kierroksissa. Siihen liitetään lähes kaikissa matkaesitteissä lauseita kuten "maailman kaunein palatsi" ja "yksin koko Romanian matkan arvoinen". (7) Peleşin linna on mukana jopa sellaisilla kierroksilla, jotka muuten keskittyvät täysin kauhu- ja vampyyriteemaan. Peleşin linnan tapaisten kohteiden mukanaolo Dracula-kierroksilla voidaan selittää kahdella tavalla. Kyseessä voi olla "linna kuin linna" -ajattelu, eli että riittää kun kyseessä on jonkinlainen linna tuomaan matkaan lisää eksotiikkaa ja kokemuksia. Toinen ja mielestäni hedelmällisempi selitys liittyy kulttuuriperintöön. On mahdollista, että Peleşin linnan tapaisia romanialaisille tärkeitä kohteita halutaan tuoda myös esiin länsimaisen ja "vieraan" vampyyri- ja kauhutematiikan rinnalle. Pekka Hakamiehen mukaan joissain tapauksissa vanhasta perinteestä on voitu pitää kiinni hiljaisena protestina vallinnutta, mutta vieraaksi koettua ideologiaa ja hallintoa kohtaan. Samalla tämä on toiminut omaa yhteisöllisyyttä ja paikallista identiteettiä ylläpitävänä voimana. (Hakamies 1998, 11.) Niitä Draculaturismin kohteita, jotka eivät liity kumpaankaan Draculaan, voidaan lähestyä samalla 


\section{TUOMAS Hovi}

tavalla. Näiden kohteiden lisääminen ja markkinoiminen voidaan nähdä protestina ulkopuolelta annettua Dracula- ja samalla myös Romania-kuvaa vastaan. Samalla yhteisöllisyyden voidaan nähdä voimistuvan ulkopuolista "uhkaa" vastaan.

Peleşin lisäksi useimmilla Dracula-kierroksilla vieraillaan kolmessa Romanian seitsemästä UNESCO:n maailmanperintökohteesta. Nämä kolme kohdetta ovat Bukovinan maalauksin koristellut luostarit, Biertanin linnoitettu kirkko ja Sighişoaran kaupungin historiallinen keskusta. (8) Näistä kohteista ainoastaan Sighişoaran kaupunki liittyy suoranaisesti jompaankumpaan Draculaan, sillä Vlad Seivästäjän oletetaan syntyneen siellä. Sighişoara mainitaan kierroksissa lähes poikkeuksetta UNESCON:n maailmanperintökohteena tai jopa Euroopan ja maailman parhaiten säilyneenä keskiaikaisena kaupunkina. Tällä tavoin luodaan yhteyttä Romanian ja muun, erityisesti läntisen Euroopan välille. Korostamalla Sighişoaraa Euroopan parhaiten säilyneenä keskiaikaisena kaupunkina korostetaan Romanian ja muun Euroopan yhteistä historiaa ja kulttuuriperintöä.

Läntisen yhteyden korostaminen voidaan nähdä sekä kommunistien hallinnon että läntisen populaarikulttuurin luoman Romanian toiseuden vastustamisena. Peleşin linnan tavoin Sighişoara on mukana myös useimmilla kauhu- tai vampyyriteemaisilla kierroksilla. Joskus tämä kulttuuriperinnön ja populaarikulttuurista tunnetun vampyyriteeman yhteys näyttäytyy melko absurdina. Esimerkiksi erään matkatoimiston vuonna 2006 järjestämän "Halloween 2006" kiertomatkan esitteessä mainitaan Sighişoara parhaiten säilyneenä keskiaikaisena kaupunkina koko Euroopassa. Tämän esittelyn jälkeen mainitaan, että kaupungin hautausmaalla voi mm. metsästää Draculan hauta-arkkua. (9) Sighişoaran tapauksessa kulttuuriperintö näyttäytyy sekä historiallisen Draculan eli Vlad Seivästäjän kautta että UNESCO:n maailmanperintökohteena (Hovi 2008a, 79).

Transilvania on niin ikään mielenkiintoinen tutkimuskohde puhuttaessa kulttuuriperinnöstä ja Dracula-turismista. Transilvania käsittää noin kolmanneksen nyky-Romaniasta ja on kulttuurisesti erittäin tärkeä alue Romaniassa. Bram Stoker aikoi alun perin sijoittaa romaaninsa tapahtumat Steiermarkiin Itävaltaan. Siirtäessään kirjansa tapahtumat Itävallasta Transilvaniaan Bram Stoker tuli Duncan Lightin mukaan samalla luoneeksi Transilvanian paikkamyytin, siis myytin Transilvaniasta mystisenä ja taianomaisena paikkana (Light 2007,749). Transilvania on Draculan tavoin muodostunut populaarikulttuurin käsitteeksi. Kun Draculasta on muodostunut arkkivampyyrin käsite tai jopa synonyymi vampyyrille, on Transilvaniasta puolestaan muodostunut käsite mystisenä, vampyyrien asuttamana taianomaisena alueena. Tämä käsite on niin vahva, että joillekin pelkkä Transilvanian olemassaolo oikeana historiallisena alueena voi olla yllättävä uutinen (Miller 2000, 143 \& 155). Transilvanian liittäminen taikauskoisuuteen ja vampyyreihin on romanialaisten kannalta ongelmallista ja kiusallista, sillä Transilvania on romanialaisille kulttuuriperinnöllisesti merkittävä alue. Transilvaniassa sijaitsee neljä Romanian seitsemästä UNESCO:n maailmanperintökohteesta. Rakennetun kulttuuriperinnön lisäksi Transilvanialla on kulttuuriperinnöllistä arvoa myös luonnonnähtävyyksiensä takia. Näin ollen Transilvanian sekä rakennetun että rakentamattoman kulttuuriperinnön törmääminen fiktiivisen vampyyrimaailman kanssa on ongelmallinen. 


\section{KULTTUURIPERINTÖ JA DRACULA-TURISMI}

\section{Kulttuuriperintö ja Dracula-turismin vastustus}

Kulttuuriperinnön merkitys näkyy Romaniassa Dracula-turismin vastustuksessa. Dracula-turismia on vastustettu, koska sen on nähty esittävän Romanian historiaa ja kulttuuria vääristyneellä tavalla. Nicolae Ceauşescun aikana Dracula-turismia vastustettiin, sillä se ei sopinut sosialistien hallituksen näkemykseen Romanian kulttuurista ja historiasta. Vlad Seivästäjän yhdistäminen länsimaisen populaarikulttuurin vampyyrihahmoon oli vastoin maan hallituksen käsitystä omasta kulttuuriperinnöstään. Erityisen hyvin kulttuuriperintöön vetoava vastustus näkyi Dracula-aiheisen teemapuiston, Dracula Parkin perustamista vastustaneiden tahojen argumentoinnissa. Teemapuistoprojektissa Romanian hallituksen tarkoituksena oli luoda positiivinen kuva Romaniasta eteenpäin suuntautuvana maana, jolla on rohkeita ja innovatiivisia ideoita ja joka on valmis ottamaan Dracula-myytin käyttöönsä omilla ehdoillaan. Projekti kuitenkin kohtasi erittäin vahvaa vastustusta sekä Romaniassa että ulkomailla. Projektin vastustajat olivat huolissaan maan maineesta ja siitä, että maa yhdistettäisiin projektin myötä lopullisesti kauhuun ja vampyyreihin (Jamal \& Tamase 2005, 446). Myös maan ja sen historian yhdistämistä vieraaseen vampyyri Dracula -myyttiin koettiin maalle haitalliseksi ja uskonnollisissa piireissä projektissa nähtiin jopa antikristillisiä piirteitä (Cosma, Pop \& Negrusa 2007, 48).

Teemapuiston sijoittaminen Sighişoaran läheisyyteen koettiin erityisen ongelmalliseksi. Jotkut historioitsijat olivat huolissaan siitä, että teemapuiston sijoittaminen Vlad Seivästäjän oletetun synnyinpaikan läheisyyteen lisäisi hämmennystä historiallisen ja fiktiivisen Draculan välillä (Light 2007, 758). (10) Sijainnin nähtiin olevan myös uhka sekä ympäröivälle luonnolle että Sighişoaran historiallisen keskustan säilymiselle. Duncan Lightin mukaan maan hallituksen yritys hyödyntää Dracula-turismia parantaakseen maan imagoa aiheutti juuri päinvastaisen reaktion. Hallitus ei aluksi näyttänyt reagoivan vastustukseen ja tuntui samalla viestittävän, ettei se piittaa maan luonnon ympäristön ja kulttuuriperinnön suojelemisesta. Yrittäessään toimia länsimaiseksi katsomallaan tavalla, Romanian hallitus antoi toiminnallaan itsestään päinvastaisen kuvan. Romanian näennäisesti vähättelevä suhtautuminen maan luontoa ja kulttuuriperintöä kohtaan antoi Lightin mukaan länsimaille kuvan Romaniasta maana, joka ei ole arvoiltaan täysin eurooppalainen. Lopulta hallitus antoikin periksi vastustukselle ja muutti suunnitelmansa. (Light 2007, 758-759.)

\section{KULTTUURIPERINTÖ KIRJALLISENA PAIKKANA}

Kulttuuriperintö ja turismi liitetään usein vahvasti fyysisiin paikkoihin, jotka ovat liittyneet joko merkittäviin tapahtumiin ja ihmisiin tai luonnonnähtävyyksiin, joille on annettu erikoisarvoa. Maantieteilijä David T. Herbert on tutkinut kirjallisia paikkoja yhtenä kulttuuriperintöturismin muotona. Kirjallisilla paikoilla Herbert tarkoittaa paikkoja, jotka liitetään joko kuuluisiin kirjailijoihin tai heidän kirjojensa tapahtumapaikkoihin. Tutkimuksensa esimerkkeinä Herbert käytti Jane Austenin ja Marcel 


\section{TuOMAS Hovi}

Proustin kirjoissaan kuvaamia paikkoja sekä paikkoja joissa kirjailijat olivat asuneet. (Herbert 1995, 32-33.)

Samaa kirjallisiin paikkoihin liittyvää turismia lukeutuu myös Draculaturismiin. Varhaisimmat Dracula-turistit tulivat etsimään ensisijaisesti Bram Stokerin kirjan juuria ja tapahtumapaikkoja, ja tämä on edelleen merkittävä osa Draculaturismia. Kirjojen tapahtumapaikkoihin liittyvä turismi herättää kysymyksiä paikkojen autenttisuudesta ja ylipäänsä autenttisuuden käsitteen käytön tarpeellisuudesta. Dracula-turismin kohteet, jotka liittyvät Stokerin kirjan tapahtumapaikkoihin, ovat historiallisessa mielessä täysin epäautenttisia ja turismia varten tuotettuja. Toisaalta turisti voi kokea vahvan yhteyden Stokerin kirjan maailmaan kävellessään kirjassa kuvatuissa maisemissa, eikä autenttisuudella ole turistin kannalta merkitystä. Herbertin mielestä eron teko historiasta tai fiktiosta kumpuavan kokemuksen välille onkin turhaa (Herbert 1995, 45).

Bram Stokerin Draculaan ja aiemmin mainittujen Austenin tai Proustin teoksiin liittyvä kirjallinen turismi on luonteeltaan hieman erilaista. Stokerin kirjan tapahtumat eivät sijoittuneet kirjailijalle tuttuun ympäristöön. Stokerin kirjan kuvaus Transilvaniasta ja varsinkin siitä vaikutteita saaneet populaarikulttuurissa esiintyneet käsitykset ovat ristiriidassa romanialaisten omasta maastaan ja kulttuurista jakaman käsityksen kanssa. Täten sillä ei ole samaa paikallista kulttuuriperinnöllistä arvoa kuin Austenilla tai Proustilla. Stokerin kirja, joskin oman alansa ehdoton klassikko, ei välttämättä koskaan tule osaksi kansainvälistä kulttuuriperintöä. Lisähaasteen kulttuuriperinnön ja historiallisen autenttisuuden vaatimukselle tuo se, ettei Stoker koskaan vieraillut kirjassa kuvaamillaan paikoilla vaan käytti lähteinään aluetta kuvaavia matka- ja historiakirjoja (Miller 2000, 148-151). Tämä historiallisen autenttisuuden puute ei toki välttämättä vaikuta turistin kokemuksen autenttisuuteen.

\section{LOPUKSI}

Kulttuuriperinnön voidaan katsoa näyttäytyvän Dracula-turismissa Romanissa suoraan Vlad Seivästäjään ja häneen liittyvien historiallisten kohteiden esiintuomisessa, muiden Dracula-hahmoihin liittymättömien mutta silti tärkeiksi katsottujen kohteiden esiintuomisessa sekä käänteisenä turismin vastustamisen kautta.

Vaikka turismin on usein nähty muodostavan uhan kulttuuriperinnölle ja sen säilymiselle, voi turismi kuitenkin toimia myös kulttuuriperintöä säilyttävänä tekijänä. Esimerkiksi Romanian suullisesta kansanperinteestä tunnettujen Vlad Seivästäjästä kertovien tarinoiden kertominen Dracula-kierroksien yhteydessä voi olla elintärkeää niiden säilymisen kannalta. Tällöin perinteen sisältö pysyy samana vaikka sen käyttöyhteys muuttuisikin.

Dracula-turismissa kulttuuriperintö näkyy kuitenkin vahvimmin oman kulttuurin puolustamisessa vieraaksi ja vahingolliseksi koettua kulttuurinmuotoa vastaan. Romanialaisessa Dracula-turismissa pyritään tuomaan myös muuta maan kulttuuriperintöä esille ja toisaalta tekemään eroa Vlad Seivästäjän ja fiktiivisen vampyyrikreivin 


\section{KULTTUURIPERINTÖ JA DRACULA-TURISMI}

välille. Sellaisten kohteiden mukanaolo Dracula-kierroksilla, joilla ei ole mitään yhteyttä historialliseen tai fiktiiviseen Draculaan on erityisen mielenkiintoista kulttuuriperinnön kannalta. Dracula-turismin kannalta kohteet ovat siis sinällään turhia tai ulkopuolisia. Silti niitä on useissa Dracula-kierroksissa, niin romanialaisten kuin ulkomaistenkin matkanjärjestäjien tarjoamilla kierroksilla, usein jopa silloin kun kierroksilta puuttuu joitain historialliseen Draculaa liittyviä kohteita. Näiden kohteiden tarjoaminen ja markkinointi on nähty erittäin tärkeäksi. Kyseessä on tulkintani mukaan maan oman kulttuuriperinnön esiin tuomista vieraaksi koetun Dracula-turismin kautta ja sen avulla.

\section{VIITTEET}

(1) Kauhuturismi on turismia, jossa turisti tarkoituksella etsii pelottavia kokemuksia kohteessa, jolla joko on tai sillä mainostetaan olevan synkkä tai pahaenteinen historia (Bristow \& Newman 2005, 215).

(2) Käytän tässä artikkelissa kulttuuriperintöä suomenkielisenä terminä vastineena englanninkieliselle termille heritage. Tiedostan kuitenkin etteivät termit välttämättä ole täysin yhteensopivat. Kulttuuriperinnön käsitteestä ja sen historiasta katso esim. Aarnipuu 2008, 17-25.

(3) "Item Menschen hat er seitlingen lassen spissen allerley volck Christen. iuden. haiden das sy sich lang haben mügen rüren vnnd zabelen vnd gewemmert durch einander als die frosch. darnach hat er in hend vnd fïß auch lasen an spissen $V$ nd hat er offt in seiner sprach gereth Ey wie groß geradigkeit treiben sy also hat er sein freud gehabt." 'Tarinan yksityiskohdat ja sanamuodot vaihtelivat eri painoksissa.

(4) Kuulin itse saman tarinan vieraillessani Arefun kylässä keväällä 2005. Tarinan yksityiskohdat, kuten oppaiden määrä ja varoittajan identiteetti vaihtelevat tarinan eri varianteissa.

(5) Tiedostan että termi "länsimainen" on tässä tapauksessa hieman hankala, sillä Romanian voidaan katsoa olevan ja aina olleen osa läntistä Eurooppaa ja länsimaita. Romanian Dracula-turismissa on kuitenkin havaittavissa useita eron tekoja länsimaisuuden ja itäeurooppalaisuuden välillä. Tässä tapauksessa "länsimaisuus" on enemmänkin poliittinen termi ja käsite, joka noudattelee vanhaa rautaesiripun jakamaa rajaa lännen ja idän välillä.

(6) Ceauşescu päätti maksaa Romanian ulkomaanvelan kokonaan pois 1980-luvulla. Tästä oli seurauksena jatkuva puute mm. elintarvikkeista, sähköstä ja lääkintäpalveluista. Kansa haluttiin kuitenkin pitää yhtenäisenä, joten ongelmat esitettiin johtuvan ulkomaista ja ulkomaalaisista. Palveluiden heikkeneminen ja epäilevä suhtautuminen ulkomaalaisiin vaikuttivat myös turismin vähenemiseen (Boia 2001, 140-144).

(7) Katso esim. "The classic Dracula tour", http://www.mysteriousjourneys.com/ en/dracula_initiation_tours/castle_dracula/travel/

(8) UNESCO World Heritage Centre, http://whc.unesco.org/en/list

(9) Quest Tours And Adventures, http://www.romtour.com/HALLOWEEN-TOUR. htm 
TuOMAS Hovi

(10) Olen itse saanut myös samanlaisen käsityksen keskusteltuani usean romanialaisen historioitsijan kanssa. Näiden historioitsijoiden joukossa oli mm. Vlad Seivästäjää tutkinut Stefan Andreescu, jonka kanssa keskustelin aiheesta huhtikuussa 2005. Muistiinpanot keskustelusta artikkelin kirjoittajan hallussa.

\section{KIRJALLISUUS}

AARNIPUU, PETJA 2008: Turun linna kerrottuna ja kertovana tilana. Helsinki: SKS.

ANDREESCU, STEFAN 1999: Vlad the Impaler (Dracula). Bucharest: The Romanian Cultural Foundation Publishing House.

BOIA, LUCIAN 2001: Romania. London: Reaktion Books Ltd.

BRISTOW, ROBERT S. \& NEWMAN, MIRELA 2005: Myth vs. Fact: An Exploration of Fright Tourism. - Bricker, Kelly, (ed.), Proceedings of the 2004 Northeastern Recreation Research Symposium. Newtown Square: U.S. Department of Agriculture, Forest Service, Northeastern Research Station.

COMPANY OF MYSTERIOUS JOURNEYS [online]. <http://www.mysteriousjourneys.com/en/dracula_initiation_tours/castle_dracula/travel/> [6.2.2009.].

COSMA, SMARANDA \& POP, CORNELIA \& NEGRUSA, ADINA 2007: Should Dracula Myth be a Brand to Promote Romania as a Tourist Destination? - Interdisciplinary Management Research (3).

ENE, GEORGETA 1976: Romanian Folklore about Vlad Țepeş. - Revue des Études Sud-Est Européennes, XIV (4).

FRAYLING, CHRISTOPHER 1992: Vampyres. Lord Byron to Count Dracula. London: Faber and Faber.

GILLE, HANS \& SPRIEWALD, INGEBORG 1968: Deutsche Texte des Mittelalters. Band LX, Die Gedichte des Michel Beheim. Berlin: Akademie-Verlag.

HALL, STUART 1999: Identiteetti. Tampere: Vastapaino

HAKAMIES, PEKKA 1998: Perinne, etninen identiteetti ja yhteiskunnan muutos. - Hakamies, Pekka (ed.), Ison karbun jälkeläiset. Helsinki:SKS.

HERBERT, DAVID T 1995: Heritage as Literary Place. - Herbert, David T (ed.), Heritage, Tourism and Society. London: Mansell Publishing Limited. A Cassell imprint.

HOVI, TUOMAS 2008a: Dracula Tourism and Romania. - Miloiu, Silviu \& Stanciu Ion \& Oncescu, Iulian (eds.), Europe as Viewed from the Margins. An East-Central European Perspective from World War I to Present. Târgovişte: Valahia University Press.

HOVI, TUOMAS 2008b: Tradition and History as Building Blocks for Tourism. The Middle Ages as a Modern Tourism Attraction. Valabian Journal of Historical Studies, Issue no.10 / 2008.

IORDANOVA, DINA 2007: Cashing in on Dracula: Eastern Europe's Hard Sells. Framework 48, No. 1.

JAMAL, TAZIM \& TANASE, ANIELA 2005: Impacts and Conflicts Surrounding Dracula Park, Romania: The Role of Sustainable Tourism Principles. Journal of Sustainable Tourism Vol. 13, No. 5. 
TuOMas Hovi

KARVONEN, ERKKI 1997: Imagologia. Imagon teorioiden esittelyä, analyysiä ja kritiikekiä. Tampere: Tampereen yliopisto.

LIGHT, DUNCAN 2007: Dracula Tourism in Romania. Cultural Identity and the State. - Annals of Tourism Research, 34(3).

LINDHOLM, CHARLES 2008: Culture and Authenticity. Malden: Blackwell Publishing.

MCNALLY, RAYMOND T. \& RADU FLORESCU 1994: In Search of Dracula. New York: Houghton Mifflin Company.

MILLER, ELIZABETH 2000: Dracula. Sense \& Nonsense. Essex: Desert Island Books Limited.

MILLER, ELIZABETH 2006: Getting to Know the Un-dead: Bram Stoker, Vampires and Dracula. - Day, Peter (ed.), Vampires. Myths and Metaphors of Enduring Evil. Amsterdam: Rodopi.

MURGOCI, AGNES 1998: The vampire in Roumania. - Dundes, Alan (ed.), Vampire. A Casebook. Wisconsin: The University of Wisconsin Press.

PERRIE, MAUREEN 1987: The Image of Ivan the Terrible in Russian Folklore. Cambridge: Cambridge University Press.

PERKOWSKI, JAN LOUIS 1998: The Romanian Folkloric Vampire. - Dundes, Alan (ed.), The Vampire. A Casebook. Wisconsin: The University of Wisconsin Press.

QUEST TOURS AND ADVENTURES [online]. <http://www.romtour.com/ HALLOWEEN-TOUR.htm> [6.2.2009].

STIREDTER, JURIJ 1961: Die Erzählung von walachischen Vojevoden Drakula Zeitschrift für Slavische Philologie XXIX.

TIMOTHY, DALLEN J \& BOYD, STEPHEN W 2003: Heritage Tourism. Essex: Pearson Education Limited.

TREPTOW, KURT 2000: Vlad III Dracula. The Life and Times of the Historical Dracula. Iaşi: The Center for Romanian Studies.

UNESCO WORLD HERITAGE CENTRE [online]. < http://whc.unesco.org/en/ list> [6.2.2009.].

ZIMMERBAUER, KAJ 2001: "Kulttuurimatkailu mielikuvayhteiskunnassa", - Riukulehto, Sulevi (ed.), Perinnettä vai bisnestä. Jyväskylä: Atena Kustannus Oy.

FM Tuomas Hovi on folkloristiikan jatko-opiskelija Turun yliopistossa Kulttuurien tutkimuksen laitoksella. Hänen väitöskirjatutkimuksensa käsittelee perinteen käyttöä Dracula-turismissa Romaniassa. 